\title{
Analysis of Stable Isotope Contents of Surface and Underground Water in Two Main Geological Formations in the Northern Region of Ghana
}

\author{
K. B. Pelig-Ba \\ Faculty of Applied Sciences, University for Development Studies, Navrongo Campus, P. O. Box 24, \\ Navrongo, UE/R, Ghana \\ E-mail:kbpeligba@yahoo.com
}

\begin{abstract}
Stable isotope $\left({ }^{18} \mathrm{O}\right.$ and $\left.{ }^{2} \mathrm{H}\right)$ contents of groundwater and some surface waters from the Northern Region of Ghana were studied. Transmissivity values are obtained using the screen length and hydraulic conductivity. These values were low corresponding to low groundwater recharge. The results of stable isotope content showed that groundwater is recharged from local precipitation but suffers evaporation during transit from the atmosphere to the water table. Infiltration to groundwater table is very slow resulting in low recharge. Furthermore, the isotope enrichment increases from the northeast to southwest (Voltaian to Basement Complexes) in the direction of the harmattan winds.
\end{abstract}

\section{Introduction}

Isotope fractionation is a geochemical tool used to identify groundwater origin, determine its age residence time and how it is affected by geo-hydrologic and meteorological factors. It can also be used to determine the origin and source of contaminants emanating from agricultural activities or other point sources. Factors such as altitude, evaporation, condensation, evapotranspiration, melting, freezing, chemical and biological processes (Faure, 1998) affect heavy isotope fractionation. Various studies on isotopic application in West Africa, in particular, include Edmunds \& Wright (1979), Sonntag et al. (1979) Edmund \& Walton (1980), Fontes et al. (1986), Gasse et al. (1987) and many others.

Pioneering work in Ghana on heavy isotope hydrology is attributed to Akiti $(1977,1980)$. Akiti (1987) also applied environ-mental isotopes such as ${ }^{2} \mathrm{H},{ }^{18} \mathrm{O},{ }^{3} \mathrm{H}$ (tritium) and ${ }^{14} \mathrm{C}$ to study groundwater in the foothills of the Accra Plains. Pelig-Ba et al. (1990) used ${ }^{2} \mathrm{H}$ and ${ }^{18} \mathrm{O}$ for waters in the Upper East and Upper West regions and the Accra Plains while Kortatsi \& Sekpe (1994) did a similar study using the same stable isotopes for groundwaters in the two Upper regions of Ghana. Since then, little literature is available on isotopic studies as far as groundwater hydrology is concerned, especially in the Northern Region of Ghana. There is little evidence to show whether there are deep groundwater resources in the area since wells deeper than $100 \mathrm{~m}$ have not yielded any economic water reserves in the area. The objective of the paper is to use stable isotopes (deuterium $\left({ }^{2} \mathrm{H}\right)$ and oxygen-18 $\left({ }^{18} \mathrm{O}\right)$ ) to determine the source of recharge to groundwater in the Northern Region of Ghana.

The isotopic composition of oxygen and hydrogen are reported in terms of differences of ${ }^{18} \mathrm{O} /{ }^{16} \mathrm{O}$ and $\mathrm{D} / \mathrm{H}$ $\left({ }^{2} \mathrm{H} /{ }^{1} \mathrm{H}\right)$ ratios relative to a standard called Standard Mean Ocean Water (SMOW) (Craig, 1961)

$$
\begin{gathered}
\delta^{18} \mathrm{O}=\left({ }^{18} \mathrm{O} /{ }^{16} \mathrm{O}-{ }^{18} \mathrm{O} /{ }^{16} \mathrm{O}_{\mathrm{SMOW}}\right) \times 10^{3} \\
{ }^{18} \mathrm{O} /{ }^{16} \mathrm{O}_{\mathrm{SMOW}} \\
\delta^{2} \mathrm{Hor} \delta \mathrm{D}=\left({ }^{2} \mathrm{H} /{ }^{1} \mathrm{H}-{ }^{2} \mathrm{H} /{ }^{1} \mathrm{H}_{\mathrm{SMOW}}\right) \times 10^{3} \\
{ }^{2} \mathrm{H} /{ }^{1} \mathrm{H}_{\mathrm{SMOW}}
\end{gathered}
$$

Consequently, positive values of $\delta^{18} \mathrm{O}$ and $\delta \mathrm{D}$ indicate enrichment of the sample in $\delta^{18} \mathrm{O}$ and $\delta \mathrm{D}$ as compared to SMOW, whereas negative values imply depletion of these samples relative to the standard. On the basis of large numbers of meteoritic water collected at different latitudes, it has been shown that $\delta^{18} \mathrm{O}$ and $\delta \mathrm{D}$ values of meteoritic water are linearly related and can be represented by the equation:

$\delta \mathrm{D}=8 \mathrm{~d}^{18} \mathrm{O}+10$

Data plotted on this suggests that such water is derived from the meteoritic origin. Large deviations also imply either enrichment or depletion. 


\section{Materials and methods}

Location, climate, hydrology and geology of study area

Location. The study was conducted in the Northern Region of Ghana. The Region has the largest land area (about 29.5\%) in the country and has the lowest population density. It is located between latitudes $8^{\circ}$ and $10^{\circ}$ $30^{\prime} \mathrm{N}$ and longitudes $0^{\circ} 30^{\prime} \mathrm{E}$ and $2^{\circ} 45^{\prime} \mathrm{W}$ (Fig. 1). The area is boarded to the north by the Upper East and Upper West regions, the to east by the Republic of Togo, south by the Volta and Brong Ahafo regions and west by the La Côte d'Ivoire.

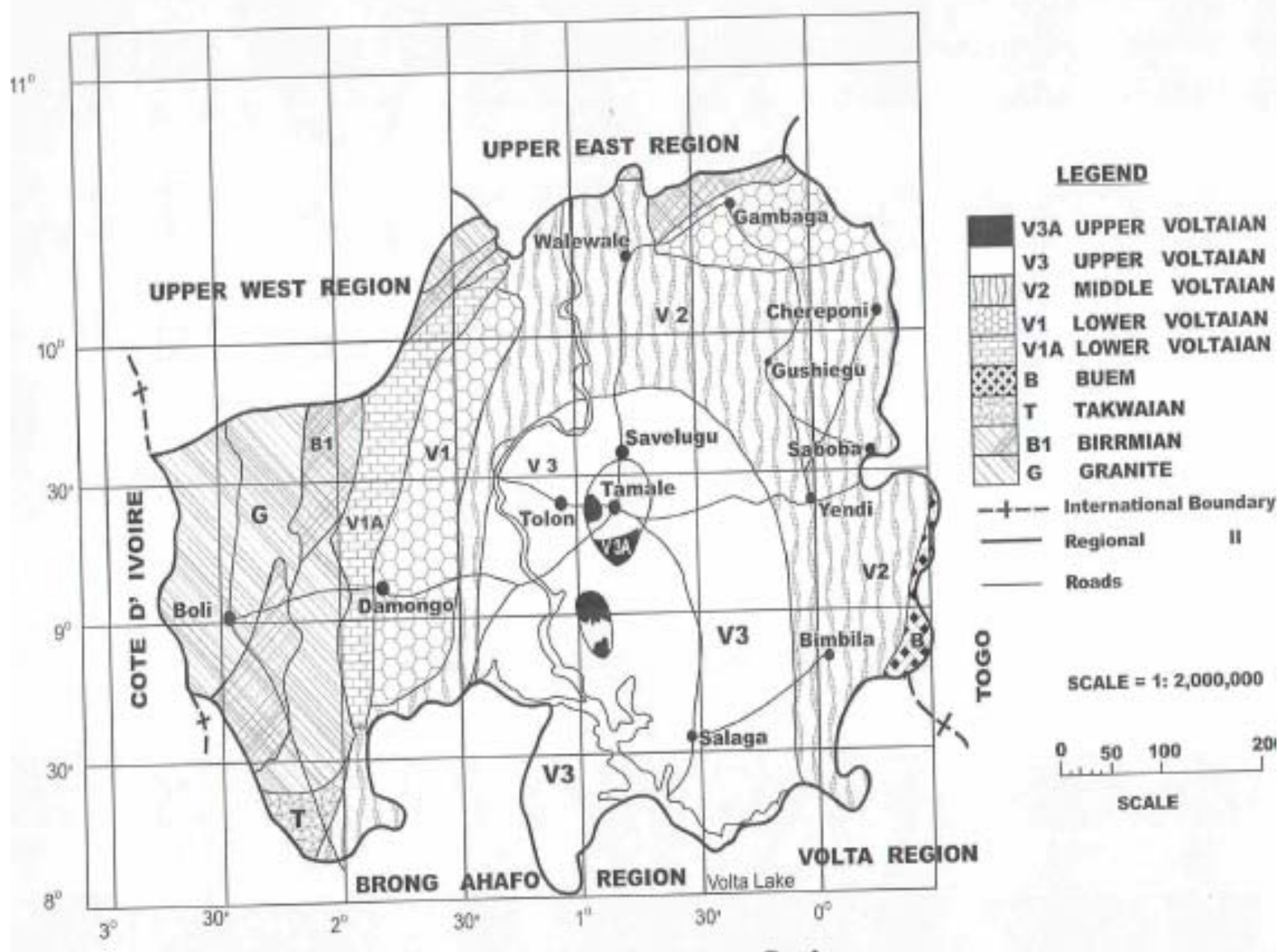

Figure 1 Location and geology of Northern Region

Climate. The climate of the study area is tropical and semi-arid. Annual precipitation averages just over $1050 \mathrm{~mm}$, while potential evapotranspiration is about $1770 \mathrm{~mm}$ (Pelig-Ba, 2000). There are only about 4-6 months of rainfall during the year, from May to October, the rest, from November to May, is relatively dry and hot. After the raining period, the northeast trade winds, locally termed the harmattan, prevails up to February/March. During the period, the weather becomes very dry and hot in the day but cools to less than 20 ${ }^{\circ} \mathrm{C}$ in the night.

Drainage system of the study area. The Black Volta, a perennial river, is one of the major rivers in Ghana, which takes its source from Mali and is found in the western part of the Northern Region. Its tributaries include the Sorri, Lambo and Gbalon, which have their sources within the Northern Region. There are other tributaries of the Black Volta, which take their sources from other regions and the country as well. The White Volta and the Oti river drain the central and the east of the Region. The major tributaries of the White Volta are the Kulpawn, Mole, Daka, Nasia and Morago. Most tributaries of both the Black and the White Volta are seasonal but the major rivers are sustained by baseflow (Pelig-Ba, 2004). Recent studies indicate that the Black Volta has a higher baseflow than the White Volta, reflecting the relative size of the two rivers (Pelig$\mathrm{Ba}, 2004)$.

There are a few highlands in the Region such as the Gambaga and Konkori that influence the hydrology of the area. Owing to the relatively steep slopes and sparse vegetation, runoff erosion is high and any evidence of this process is the fast flow of surface water from the foot of the hills during periods of rainfall.

Geology. The Northern Region can be divided into three main geological zones, the Voltaian and the Buem series forming the sedimentary formation that constitute about $75-80 \%$ of the area, and the Basement West African Journal of Applied Ecology, vol. 15, 2009 
Complex, consisting of the Birrimian rocks and granites (20-25\%) (Fig. 1). The Voltaian series is Palaeozoic and younger than both the Buem series and the Birrimian, and is located in the central to eastern part of the study area. The Voltaian series is between 3,000-4,000 m thick (Kesse, 1985). The Voltaian sedimentary formation is almost flat with a few undulating places, especially where there are high grounds created by the consolidated sediments, e.g. the Gambaga and Konkori hills. These sediments are mainly sandstones, shale, siltstones and mudstones. Sometimes the lateritic sediments form the overburden of buried rocks. The Basement Complex crops out in the western part of the Region. It does not rise to any great height but only characterised by isolated rocks outcrops.

\section{Sampling and analysis}

Estimation of aquifer properties. Data from test pumping of boreholes (without observation wells), with periods generally lasting $3 \mathrm{~h}$ or less, were used to estimate hydraulic conductivity (K) and transmissivity (T). Analytical procedures used to obtain transmissivity were type-curve and Cooper-Jacob methods, using the PTEST2 computer program (HSI, 1997). Eleven selected sedimentary rock samples were used to analyze for porosities and Klikenburg permeabilities/ hydraulic conductivities.

Water samples. Rainwater samples (15) were mostly collected in the Tamale Municipality in 1997 and 1998 from a rain gauge installed by the Meteorological Office. About 36 randomly selected groundwater samples were collected from boreholes equipped with hand pumps except one at Damongo (ADT 22), which had a submersible pump. Samples were always collected after pumping for at least 5 min if water was not already being pumped prior to arrival at the pump site. This was to purge the well of stagnant water around the pump parts. Three samples from some perennial rivers were also collected at Yapei for the White Volta, and Buipe for the Black Volta, and Mankango, about $50 \mathrm{~km}$ south of the confluence but towards the northern bank. At each point, samples were collected and filtered with $0.45 \mu \mathrm{m}$ filters into clean rinsed polyvinyl chloride bottles and acidified with 2-3 drops of Aristar $\mathrm{HNO}_{3}$.

All samples were sent to the Postgraduate Institute for Sedimentology, University of Reading in the United Kingdom for analysis. Samples were stored at temperature of about $4{ }^{\circ} \mathrm{C}$ and brought up to room temperature when required for analysis. Bicarbonate alkalinity was determined trimetrically using 0.01 and $0.1 \mathrm{MHCl}$ while calibrated $p \mathrm{H}$ meter and conductometer with a temperature function were used for $p \mathrm{H}$, specific electrical conductivity (SEC) and temperature determined in situ, respectively. These were all done at the sampling site.

Isotope analysis. To ensure quality and reproducible stable isotope data, standard procedures, as described for sample preparation and analysis, were undertaken before the start of each analysis, with the following precautions: (a) thorough cleaning of reacting vessels, (b) fresh and degassed $\mathrm{Zn}$ metal was used throughout the analysis, and (c) enough sample in reacting vessels, especially deuterium in which very little sample $(4 \mu \mathrm{l})$ was required. This was done by observing the amount of gas released from the reaction with $\mathrm{Zn}$ metal as indicated by the fractionation pressure. If this pressure was less than 25 mbar, it indicated insufficient amount of $\mathrm{H}_{2}$ gas and, hence, not enough water sample was used and, therefore, the analysis was rejected and repeated. Similarly, a higher fractionation pressure (above 35 mbar) suggested more than enough sample was used, and as such the result was similarly rejected and also repeated.

The sea mean ocean water (SMOW) was used as the external standard for both deuterium and oxygen. To improve quality of the results, randomly selected samples and some of the external standards were also reanalysed as controls. All samples were analysed in duplicate. Large standard deviations from re-analysed samples or duplicates were evidence of poor analysis. Acceptable values were within $0.01-0.05 \%$ for ${ }^{18} \mathrm{O}$ and $0.1-0.5 \%$ for ${ }^{2} \mathrm{H}$.

\section{Hydrogeology}

\section{Results}

Transmissivity is a fundamental property of aquifers and water-bearing materials. In homogeneous aquifers, transmissivity is the product of hydraulic conductivity $(\mathrm{K})$ and the saturated aquifer thickness (b), that is $\mathrm{T}=$ $\mathrm{Kb}$. The saturated thickness $\mathrm{b}$ was obtained using the screen length of each well. Boreholes are normally drilled into granites and metamorphic rocks such as gneisses and schists of the Basement Complex to diameters of about $216 \mathrm{~mm}$. The complex nature of the geology results in variability of groundwater in both quality and quantity. Groundwater is obtained from fracture zones rather than extensive aquifers with screen lengths, ranging 8-28 $\mathrm{m}$ in the Basement Complex and 1-32 $\mathrm{m}$ in the Voltaian series.

Transmissivity values for the Basement Complex ranged from 0.40 to $27.0 \mathrm{~m}^{2} \mathrm{day}^{-1}$ and are characteristic of basement aquifers (UNESCO, 1984). The hydraulic conduc-tivities also ranged from 0.05 to $3.39 \mathrm{~m}^{-1 a y}{ }^{-1}$, with an arithmetic mean of $0.50 \mathrm{~m} \mathrm{day}^{-1}$, and were also generally low for sedimentary formation. The transmissivity West African Journal of Applied Ecology, vol. 15, 2009 
values ranged from $0.17 \mathrm{~m}^{2} \mathrm{day}^{-1}$ to $23.00 \mathrm{~m}^{2}$ day $^{-1}$ for the Voltaian series. Few boreholes had trans-missivity values above $20 \mathrm{~m}^{2}$ day $^{-1}$.

The porosity of Lower Voltaian (V1) samples was found to be the highest while those from the Middle Voltaian (V2) appeared to be the least porous. The highest porosity obtained was $17.9 \%$ at Damongo, and the least was 3.0\% at Wajoga, both located in the V1 series. Results for porosities and Klikenburg permeabilities/hydraulic conductivities are shown in Table 1. Values for boreholes in the V3 and V1 were lower than in the V2, which ranged from 0.20 to $22.8 \mathrm{~m}^{2}$ day ${ }^{-1}$. The range in the V1 was $0.30-9.30 \mathrm{~m}^{2} \mathrm{day}^{-1}$ and in the V3, it was $0.20-18.30 \mathrm{~m}^{2} \mathrm{day}^{-1}$. Screen lengths for boreholes in the V2 series ranged from 4.00 to $31.70 \mathrm{~m}$, with corresponding $\mathrm{K}$ values ranging from $8.00 \times 10^{-3}$ to $3.42 \mathrm{~m} \mathrm{day}^{-1}$.

TABLE 1

Laboratory values of porosities and Klikenburg permeabilities and hydraulic conductivities of rocks in the Voltaian series (b.d. = below detection)

\begin{tabular}{lllll}
\hline Location & Series & Rock types & Porosity $(\%)$ & $K\left(\mathrm{~m} \mathrm{~d}^{-1}\right.$ \\
\hline Bunkprugu & V1 & Sandstone & 10.3 & $1.20 \times 10^{-3}$ \\
Damongo & V1 & Sandstone & 17.9 & 1.62 \\
Sakogu & V1 & Sandstone & 12.5 & $1.20 \times 10^{-3}$ \\
Tempiela & V1 & Sandstone & 15.0 & 0.72 \\
Karaga & V2 & Mudstone & 3.9 & $4.20 \times 10^{-5}$ \\
Demon & V2 & Sandstone & 5.6 & b.d. \\
Lanja & V2 & Sandstone & 4.4 & b.d. \\
Wajoga & V2 & Sandstone & 3.0 & b.d. \\
Yendi & V2 & Sandstone & 9.1 & $3.20 \times 10^{-5}$ \\
Sang & V2 & Sandstone & 9.7 & $4.50 \times 10^{-2}$ \\
Alipe & V3 & Shale & 9.3 & $6.40 \times 10^{-6}$ \\
\hline
\end{tabular}

Weathering of bedrock produces overburdened materials, some of which are indurated into hard lateritic pans. The thickness of the overburden varies within the area. Groundwater, therefore, occurs below this overburden and in fractures within the bedrock. Borehole depths in the Basement Complex ranged from $22 \mathrm{~m}$ at Nyoli to $66 \mathrm{~m}$ at Bole, and both are having yields of 75 litres $\mathrm{min}^{-1}$.

Deeper boreholes do not always imply higher yields. Yields up to 600 litres $\mathrm{min}^{-1}$ have been encountered in a few boreholes at Gbebire and Kpongori. Borehole yields appear to be related to elevation. Fig. 2 is a plot of borehole yield against elevation, which shows an inverse relationship, suggesting that boreholes on high ground are more likely to produce lower yields.

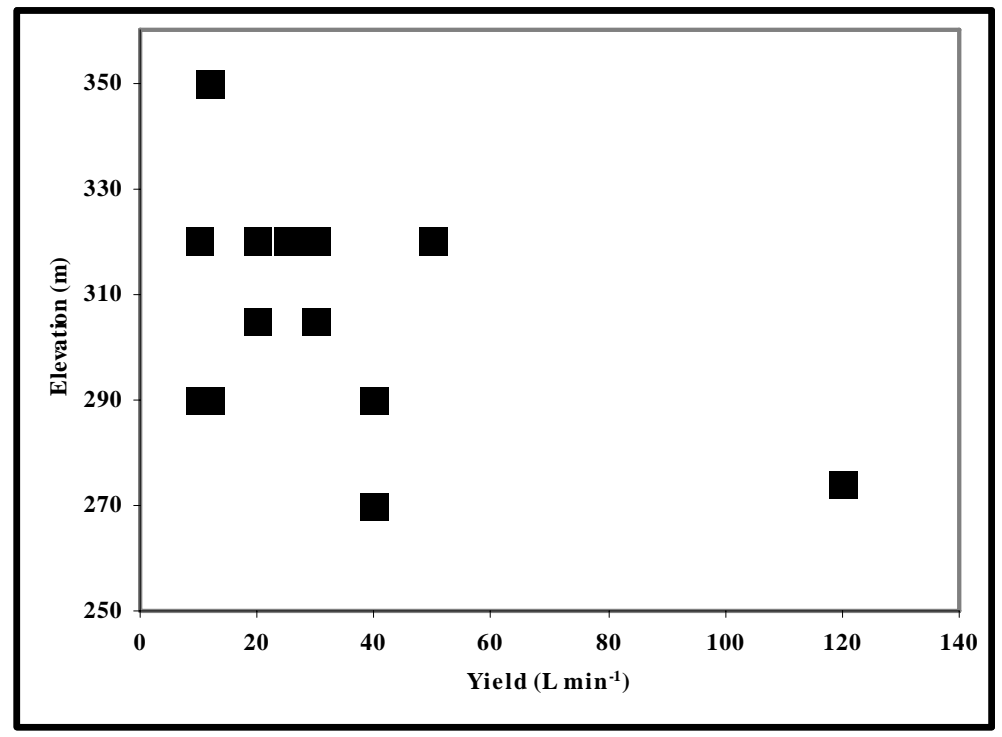

Fig. 2. Plot of borehole yield against elevation in study area

Results of stable isotope. The results of the stable isotopes are presented in Table 2. The means for the rain water are $-1.5{ }^{18} \mathrm{O}$ and $-10.5{ }^{2} \mathrm{H}$, while the ranges are -5.6 to $-1.7{ }^{18} \mathrm{O}$ and -44.2 to $-6.0{ }^{2} \mathrm{H}$. Stable isotope compositions of both groundwater and surface water were plotted together with those for rainfall collected at Tamale (Fig. 3). A local meteoric water line (LML), derived from plotting the rainwater samples, was 
obtained using regression analysis. The Global Meteoric Water Line (GMWL) was inserted together with that obtained by Akiti (1987) for the Accra Plains in the south-eastern part of Ghana. The GMWL equation is given by:

$$
\delta^{2} \mathrm{H}=8 \delta^{18} \mathrm{O}+10
$$

where $\delta$ is the isotopic enrichment parameter, $\mathrm{r}^{2}$ is the linear regression constant, $\mathrm{O}$ and $\mathrm{H}$ are heavy isotopes of oxygen and hydrogen. The regression equation for the rainwater samples is:

$$
\delta^{2} \mathrm{H}=6.9 \delta^{18} \mathrm{O}-0.19, \mathrm{r}^{2}=0.91
$$

The Akiti's line equation for the Accra Plains is given by:

$$
\delta^{2} \mathrm{H}=7.86 \delta^{18} \mathrm{O}+13.61
$$

The regression equation obtained for both the groundwater and surface water samples was:

$$
\delta^{2} \mathrm{H}=5.7 \delta^{18} \mathrm{O}-7.3, \mathrm{r}^{2}=0.58
$$

TABLE 2 cont'd

Isotope composition of rainwater and groundwaters from the Voltaian Formation in the study area

\begin{tabular}{llllll}
\hline Location & ${ }^{18} \mathrm{O}^{\circ}{ }_{\text {oo }}$ & ${ }^{2} \mathrm{H}^{\circ}{ }_{\text {oo }}$ & Location & ${ }^{18} \mathrm{O}^{\circ}{ }_{\text {oo }}$ & ${ }^{2} \mathrm{H}^{\circ}{ }_{\text {oo }}$ \\
\hline Tarkpa & -2.7 & -23.2 & Gnani & -4.6 & -40.6 \\
Diari East & -4.0 & -32.8 & Sung 2 & -3.6 & -33.0 \\
Nanton East & -2.8 & -25.6 & Gunsi & -3.6 & -36.2 \\
Tampion & -2.7 & -23.8 & Bunkpurugu & -4.3 & -34.2 \\
Nanton hand dug well & -2.3 & -21.3 & Busunu & -4.1 & -29.1 \\
Tamale Sec & -2.6 & -21.4 & Damongo & -3.7 & -24.5 \\
Kpembe & -2.9 & -22.8 & Anyanto & -2.8 & -27.7 \\
Kpandai & -3.2 & -31.9 & Mankarigu & -3.4 & -21.9 \\
Bimbila Sec & -2.8 & -26.3 & Jawani & -2.2 & -32.7 \\
Pusiga 1 & -2.8 & -25.5 & Gongopa & -3.5 & -26.2 \\
Pusiga 2 & -3.1 & -22.7 & Mankango & -0.5 & -13.8 \\
Malzeri & -3.8 & -29.4 & White Volta R*. & -0.5 & -13.6 \\
Gushiegu Hosp & -3.1 & -28 & Black Volta R*. & -2.4 & -22.8 \\
Piong & -4.1 & -30.4 & Mean & -3.0 & -26.6 \\
Saboba & -3.3 & -26.8 & Min. & -4.6 & -40.6 \\
& & & Max. & -0.5 & -13.6 \\
\end{tabular}

The plot gives a lower correlation coefficient than the rainwater samples probably owing to local effects that may cause local deviations in isotopic content in groundwater. Some samples are plotted on or near the LML while others were relatively further away from the line (Fig. 3). Those that were plotted closer or on the line are likely to be recharged directly from local precipitation with little evaporation.

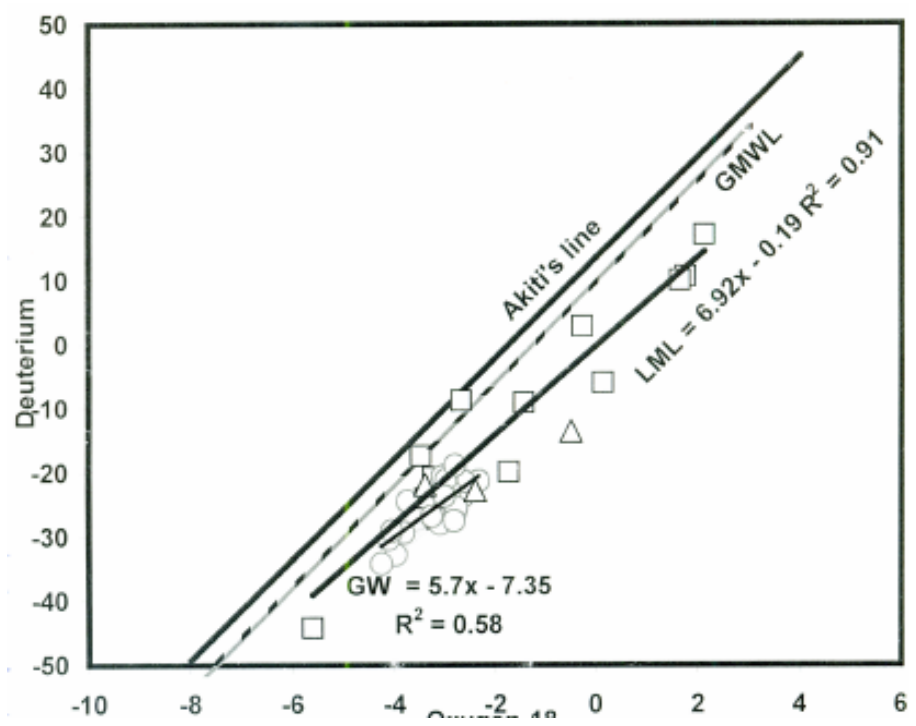

Fig. 3. Stable isotope plot showing the relationship between groundwater (circles) and rainfall (squares) and surface water (triangles) 
The range and means in the two geological units also suggest that groundwaters in the Voltaian series are more depleted in the two heavy isotopes than the Basement Complex. Those plotted closer or on the line are likely to be recharged directly from local precipitation with little evaporation. If the mean isotopic contents of the groundwater in the two geological formations is compared to that of the rainwater, it is observed that the rainwater is relatively more enriched which can be attributed to a number of reasons including (i) rainfall might have suffered some level of evaporation before reaching the groundwater table, (ii) groundwater might not have been recharged from the local precipitation but from distant sources, and (iii) isotopic exchange between enriched groundwater and aquifer materials, thus, reducing the amount of heavy isotope content in the former as compared to the rainfall.

Moreover, comparing the ranges and means of the two geological units it is observed that groundwaters in the Voltaian series are more depleted in the two heavy isotopes than the Basement Complex. This could also be attributed to higher canopy in which evaporation of heavier isotopes is comparatively more reduced than the lighter ones. A close examination of the ground-waters along the north-eastern margin shows that they are more depleted than those of the south-west (Fig. 4). For example, the Gnani and Bunkprugu boreholes had isotopic compositions of $-4.6{ }^{18} \mathrm{O}$ and $-40{ }^{2} \mathrm{H} \%$, and $-4.3{ }^{18} \mathrm{O}$, and $-34.2{ }^{2} \mathrm{H} \%$, respectively, and are comparatively lower than Salaga $\left(-2.9{ }^{18} \mathrm{O},-22.8{ }^{2} \mathrm{H} \%\right)$ and Wagawaga $\left(-2.4{ }^{18} \mathrm{O},-23.7{ }^{2} \mathrm{H} \%\right)$ in the south and south-west of the study area. This incidentally is the direction of the NE trade winds (harmattan), resulting in differential evaporation rates, thus, leading to the enrichment of heavy isotope with distance. This is also in the direction of increasing vegetative cover.

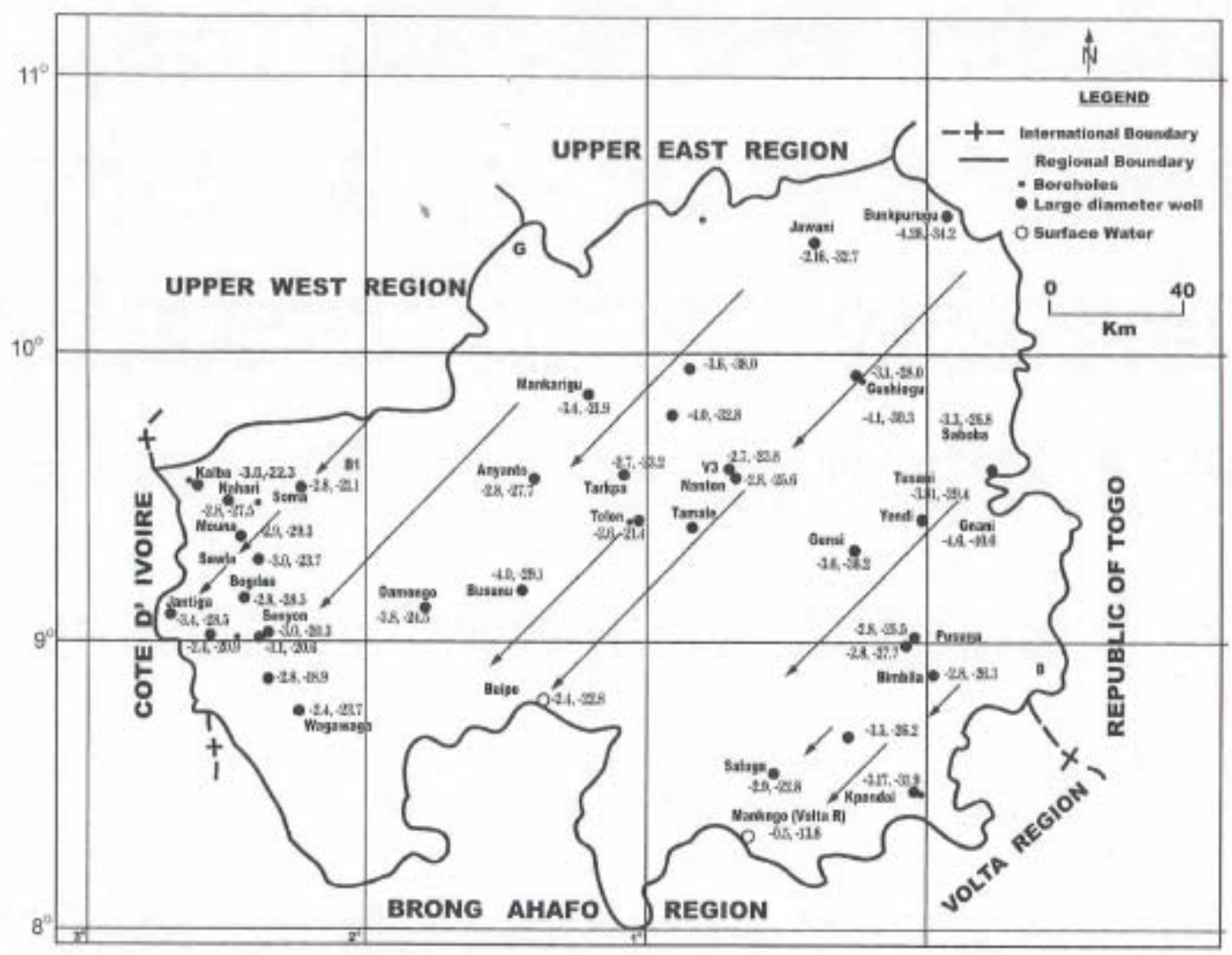

Figure 4: Stable isotope map showing the direction of enrichment

The confluence of the Volta river at Mankango had similar isotope content as the White Volta but more enriched than the Black Volta. The isotopic content of any river is the contributions of the various tributaries and their geographic locations. The White Volta tributaries take their sources further into the Ssahalien zone than that of the Black Volta, and would have more enriched isotopic content due to evaporative effects. At the confluence, it could be that the sample was taken from where the water was predominantly from the White Volta portion, since any well-mixed water will be a proportional contribution of main rivers feeding into the confluence. This is confirmed by the point where the sample was collected, i.e. the northern site of the river which is the direction from which the White Volta flows into. Moreover, the isotopic content of the White Volta was more positive than that of the Black Volta. This is explained that the Black Volta is much larger 
than the White Volta and contains a greater quantity of water, thus, suggesting that evaporation will have more effect on the one with smaller quantity, i.e. the White Volta than the Black Volta.

Generally, enrichment increases towards the south-west to the Basement Complex (Fig. 4), except at Jawani, which is located in the north-east that appears to be slightly more enriched than Damongo and Sawla. This could be a local event but the general trend is because there is a higher forest cover than that in the northeast of the study area, suggesting that rain drops, which have been intercepted by denser vegetative cover, is accompanied by evaporation of lighter isotopes, which have fallen under the canopy while the heavier ones infiltrate into the groundwater table. Hence, higher forest cover has greater influence on heavy isotope enrichment. The enrichment in stable isotope value also increases from the northern part to the south of the study area of the Basement Complex, and also in the direction of higher forest density.

\section{Discussion}

The transmissivity results showed that infiltration of rain water is low in the area. This is also coupled with low porosities of the two geological formations while that of the Basement Complex can be attributed to inadequate fissuring. The Voltaian, on the other hand, is due to high degree of consolidation and low fissuring. The implication is that rain water will not easily be percolated but be removed from the surface by evapotranspiration and fast runoff. The presence of hard and non-transmissible pan underneath the topsoil also constitutes significantly to evapotranspiration and runoff. In comparison, the Basement Complex has higher hydraulic conductivity and transmissivity than the Voltaian series, which explains why the groundwater potential in the western part of the Basement Complex is higher. Secondary porosity, created by fracturing and weathering of bedrock and overburden material, enhances infiltration in the Basement Complex than in the Voltaian.

The line attributable to Akiti (1987) is similar to the GMWL except the deuterium excess. It, however, differs from the LML obtained from this study in both the deuterium excess and $\delta^{18} \mathrm{O}$ coefficient. This $\delta^{18} \mathrm{O}$ coefficient is humidity-dependent (Dansgaard, 1964; Mazor, 1991), and probably explains why the coefficient of Akiti's line is higher since his study considered only samples within the Accra Plains. The climate of the Accra Plains is influenced by the Atlantic Ocean where the relative humidity is higher and more uniform than in the Northern Region, which is located in the dry savanna climatic zone. Hence, samples from the savanna zone could be more evaporated, leading to relatively higher enrichment of ${ }^{2} \mathrm{H}$ and ${ }^{18} \mathrm{O}$ composition. The value of the slope of the isotopic groundwater (Equation 4) is less than LML but greater than 5 . This indicates that evaporation of precipitation during recharge to groundwater may be taking place either in the free surface or on the raindrops before reaching the soil zone (Allison \& Hughes, 1982; Harrington \& Herczeg, 1998).

A clustering of groundwater samples observed in Fig. 3 suggests that both evaporation and isotopic exchange with aquifer minerals may be occurring in the system. This is also supported by the fact that some groundwater samples below the LML appear enriched, which is probably due to either evaporation during transit or isotopic exchange with aquifer materials such as silicate minerals richer in $\delta^{18} \mathrm{O}$ (Domenico \& Schwartz, 1990). However, some samples are found above the LML, suggesting a recent recharge history but they may have suffered evaporative effects, resulting in some fractionation, thus, leading to an enrichment of the groundwaters.

Samples with similar isotopic composition as the precipitation, as indicated by those plotted on the LML, are regarded as recharging directly from local precipitation through preferential flow channels such as cracks or fractured zones (Mathieu \& Bariac, 1996). In this case, rainwater flows through macro pores and preferential flow channels to the water table with little mixing taking place (Clark \& Fritz, 1997). The open crevices and fractures in some selected places in the Basement Complex allow easy heat flow into the water table to cause more evaporation than the relative effect of capillary heat flow into the water table usually observed in sedimentary terrains such as the Voltaian. This explains the relatively higher isotopic enrichment observed in the Basement Complex than the Voltaian series.

It is known that recharge to groundwater by precipitation is higher in places of lower forest cover than the highly forested areas (Peck \& Williamson, 1987). Recharging rainwater with more depleted stable isotopes dilutes the already existing groundwater. Evapotranspiration is lower in the less forested than in the more forested areas because in the former little transpiration occurs in groundwater below $6 \mathrm{~m}$. However, transpiration normally removes more of the lighter isotopes and, therefore, enriching groundwater with the heavier isotopes. Furthermore, obstruction by vegetative cover may prevent part of the rainfall reaching the land surface, and lighter isotopes may then be evaporated into the atmosphere. The heavier isotopes on the vegetation cover drop into the soil and find their way into the groundwater table, thus, leading to the enrichment in forest areas. 


\section{Conclusion}

The study has shown that groundwater was recharged predominantly from precipitation. However, the recharging water might have undergone some evaporation in the atmosphere or in the soil zone before reaching the groundwater table. Isotopic exchange process between recharging water and aquifer materials was possible since some silicate materials can be enriched in heavy isotopes of hydrogen and oxygen. The fractured nature of the rock of the Basement Complex and the Voltaian series allows some degree of infiltration. However, due to limited transmissivity, recharge is slow, enhancing evaporation, isotope fractionation, and exchange processes.

\section{References}

Akiti T. T. (1980). Etudé géochimique et isotopique de quelqués aquifers du Ghana. (Thesis.) Univeristé Paris-Sud. 232 pp.

Akiti T. T. (1977). Groundwater flow in weathered granite in the Tamne basin, North Eastern Ghana.

Akiti T. T. (1987). Environmental isotope study of groundwater in crystalline rocks of the Accra Plains, Ghana. Proceedings of the 4th Working Meeting, Isotopes in Nature, Leipzig, September 1986.

Allison G. B. and Hughes M. W. (1978). The use of environmental chloride and tritium to estimate total recharge in an unconfined aquifer. Aust. J. Soil Res. 16: 181-195.

Clark I. and Fritz P. (1997). Environmental Isotopes in Hydrogeology. Lewis Publishers.

Dansgaard W. (1964). Stable isotope in precipitation. Tellus XVI: 436-468.

Domenico P. A. and Schwartz F. W. (1990). Physical and Chemical Hydrogeology. John Wiley and Sons, New York.

Edmunds W. M. and Wright E. P. (1979). Groundwater recharge and paleo-climate in the Sirte and Kufra Basin, Libya. J. Hydrol. 40: $215-235$.

Edmunds W. M and. Walton N. R. C. (1980). A geochemical and isotopic approach to recharge evaluation in semi-arid zones. Proceedings of the Advisory Group Meeting on the Application of Isotope Techniques in Arid Zone Hydrology, Vienna, i978. International Atomic Energy Agency (IAEA), Vienna.

Fontes J. C., Yousfi M. and Allison G. B. (1986). Estimation of long-term diffuse groundwater discharge in the northern Sahara using stable isotope profiles in soil water, J. Hydro. 86: 315.

Gasse F., Fontes J. Ch., Carbonel F., Plaziat J. C., Soulie_Marsche I., Kaczmarcska I. and Dupeuble P. A. (1987). Biological remains, geochemistry and stable isotope for the reconstruction of environmental and hydrological changes in the Holocene lakes from North Sahara, Palaeo 3 (60) 1-46.

Harrington G. A and Herczeg A. L. (1998). A geochemical model for the arid Ti-Tree Basin, Central Australia, In Water-Rock Interaction. (Arehart and Hulston, ed.), pp. 231-234, Balkema.

Hydrogeological Services International (HSI) Ltd (1977). Test Pumping Analysis Software (PTEST2), Version 2.1. Guildford, U.K.

Kesse G. O. (1985). The Rock and Mineral Resources of Ghana. A. A. Balkema/Rotterdam/Boston.

Kortatsi B. K. and Sekpey N. K. (1994). Chemical and isotopic techniques for the origin of groundwater in the crystalline basement complex of the Upper Region of Ghana. Regional trends in Geolgy in African Geology. Proceedings of the 9th International Geological Conference, Accra, 2nd-7th November, 1992). Geological Society of Africa.

Mathieu R. and Bariac T. (1996). An isotopic study $\left({ }^{2} \mathrm{H}\right.$ and $\left.{ }^{18} \mathrm{O}\right)$ of water movements in the clayey soils under semi-arid climate. Wat. Resour. Res. 32: 779-789.

Mazor E. (1991). Chemical and Isotopic Groundwater Hydrology, 2nd edn. Marcel Dekker, New York.

Peck A. J. and Williamson D. R. (1987). Effects of forest clearing on groundwater. J. Hydrol. 94: 47-65.

Pelig-Ba K. B. (2000). Hydrogeochemistry of the Birrimian Metasediments and the Voltaian Sediments of the Northern Region of Ghana. (PhD Thesis.) University of Reading, Reading, U.K.

Pelig-Ba K. B. (2004). Estimation of water balance in the Northern Region of Ghana, Ghana J. Dev. Stud. 1 (2): $118-141$.

Pelig-Ba K. B., Kortatsi B. K. and Edmunds W. M. (1990). Application of isotope techniques in Groundwater studies in the Upper Regions of Ghana. Paper presented at the Regional Seminar on Isotope in Hydrology for Developing Ccountries in Africa from 15th to 19th October 1990 in Vienna, Austria.

Sonntag C., Klitsch E., Lohnert E. P., El Shzly E. M., Munnich K. O., Junghans C., Thornweithe V., Weistroffer K. and Swalem F. M. (1979). Palaeoclimatic information from deuterium and oxygen-18 in carbon-14-dated north Saharan groundwaters: Groundwater formation in the past, Isotope Hydrology. Proc. Symp. Neuherberg 1978). IAEA, Vienna. 569 pp.

UNESCO (1984). Groundwater in hard rocks. Project 8.6 of the International Hydrological Programme. Studies and Reports in Hydrology No 23. 